\title{
Submesoscale Eddy Structures and Frontal Dynamics in the Barents Sea
}

\author{
O. A. Atadzhanova ${ }^{1,2, *}$, A. V. Zimin ${ }^{1}$, E. I. Svergun ${ }^{1,2}$, A. A. Konik ${ }^{1,2}$ \\ ${ }^{1}$ Shirshov Institute of Oceanology, Russian Academy of Sciences, Moscow, Russian Federation \\ ${ }^{2}$ Russian State Hydrometeorological University, Saint-Petersburg, Russian Federation \\ *e-mail: oksana.atadzhanova@gmail.com
}

Complex analysis of spatial and temporal variability of surface manifestations of the submesoscale eddies in the Barents Sea is carried out based on generalization of a large amount of satellite SARimages of ENVISAT ASAR obtained in course of the warm periods in 2007 and 2011. The relationship between the eddy structures and the frontal dynamics is also quantitatively evaluated. It is found that the submesoscale eddies represent a widespread phenomenon in the sea. They are most often observed to the northwest off the Franz Josef Land, near the eastern coast of the Western Spitsbergen, between the Franz Josef Land and the Novaya Zemlya, in the southwestern part of the sea and near the Kanin Nos peninsula. But their absolute maximum is recorded to the northeast off the Rybachy Peninsula. In both years the eddy activity peak falls on July. Though the diameters of the eddies under study vary from 0.2 to $25 \mathrm{~km}$, those with the diameters $2-4 \mathrm{~km}(\sim 45 \%)$ and of a cyclonic rotation type $(\sim 80 \%)$ are the most numerous. Being analyzed, the sea surface temperature data permit to reveal significant mesoscale and synoptic dynamics of the frontal zones and the associated frontal boundaries throughout the entire sea in course of the whole warm season. Comparison of the eddy locations with variability of the fronts' positions for each month (based on the data of 2007) shows that the submesoscale structures are often recorded within these regions (up to $50 \%$ ). The period of the highest eddy activity in July coincides with that of the strongest synoptic and mesoscale dynamics of the fronts.

Keywords: submesoscale eddy, satellite radar image, sea surface temperature, thermal frontal zone, Polar front, Marginal ice or Arctic front, the Barents Sea.

Acknowledgements. The research was carried out within the framework of State Order No. 01492018-0014 "Wave processes, transport phenomena and biogeochemical cycles in the seas and oceans: the study of forming mechanisms on the basis of physical-mathematical modeling and in situ experimental works".

For citation: Atadzhanova, O.A., Zimin, A.V., Svergun, E.I. and Konik, A.A., 2018. Submesoscale Eddy Structures and Frontal Dynamics in the Barents Sea. Physical Oceanography, [e-journal] 25(3), pp. 220-228. doi: 10.22449/1573-160X-2018-3-220-228.

DOI: $10.22449 / 1573-160 \mathrm{X}-2018-3-220-228$

(C) 2018, O. A. Atadzhanova, A. V. Zimin, E. I. Svergun, A. A. Konik

(C) Physical Oceanography

Introduction. The Barents Sea is located in polar regions, characterized by harsh climatic conditions. Its greater part (except for the southwestern one) is covered by ice during the winter. This is because oceanographic conditions are formed by currents under the heat advection effect [1]. The interaction of comparatively warm Atlantic waters and cold waters of the Arctic Ocean occurs in the Barents Sea. It determines the formation of the Polar frontal zone in the central part of the sea and the Marginal Ice frontal zone in its northern part [2-4]. The structures and characteristics of the frontal zones and fronts in them are different according to the data of different authors [2, 5-8]. There is no detailed description of the mesoscale and synoptic dynamics of these frontal zones and fronts in the literature. Descrip- 
tions of frontal zones in the water area of the entire Barents Sea are generally based on the generalization of the data of long-term hydrological observations and illustrate their average position, but not the mesoscale dynamics during the ice-free pe$\operatorname{riod}[2,7,9]$.

Meanders and eddies can be formed due to instability along the fronts. The existence of mesoscale eddy structures in the Polar frontal zone on the border with the Norwegian Sea was noted in $[10,11]$. In the works $[2,12]$ eddies with a diameter ranging from one to tens of kilometers are mentioned. Such eddies are revealed during the polygon surveys in the northwestern Barents Sea and in the region of the Great (Perseus) Bank. Satellite data also permitted to record anticyclonic and cyclonic meanders near the Polar frontal zone [13] and submesoscale eddies in the entire water area [14]. So far, however, there has been no specialized research of the features of the spatial variability of the characteristics of small (submesoscale) eddies in the sea area for several years. In addition, there are no evaluations of the relationship between frontal dynamics and the features of the formation of small eddies, which can significantly affect the processes of vertical and horizontal exchange in the water area of the sea. The present study is aimed to describe the intraseasonal and interannual features of the manifestations of submesoscale eddies and to compare them with the variability of the position of fronts during the warm season in the Barents Sea.

Materials and methods. To detect small (submesoscale) eddy structures in the Barents Sea 1203 and 838 satellite SAR-images of ENVISAT ASAR respectively in June - October 2007 and 2011 in the C-band and WSM (swath width is 400 kilometers, a spatial resolution $-150 \mathrm{~m}$ ) and IMP (100 km and $25 \mathrm{~m}$, respectively) shooting modes. The choice of 2007 and 2011 years is due to the fact that in these years the minimum ice area in the sea area was observed [15]. On average, the coverage of the Barents Sea was 120 images SAR mages, while in 2011 its southeastern part was not practically covered by SAR images. So, in the both years the maximum coverage (over 200 images) fell within the northern part of the sea. According to this data, the variability of the position, diameters and the rotation type of the eddy structures was evaluated.

To obtain an idea of the position of the fronts, the sea surface temperature and gradient fields were used. The fields were calculated from the daily sea surface temperature - of the GHRSST product (Global Foundation Sea Surface Temperature Analysis) Level 4 OSTIA (Operational Sea Surface Temperature and Sea Ice Analysis) with $0.05^{\circ}$ resolution by latitude and longitude from June to October 2007 and 2011. Based on this data, the averaged (monthly and decadal) fields of temperature and its gradient were calculated, according to which the positions of frontal zones and fronts were determined. In accordance to three mean meridional sections along $20^{\circ}, 35^{\circ}$ and $50^{\circ} \mathrm{E}$ for the frontal zones their mean width, maximum and average gradients were estimated. To compare the obtained data on fronts and eddy structures, composite maps were monthly constructed. They combined the position of the eddies and the ten-day position of fronts and frontal sections. Maps were constructed for the June - September 2007 period. 
Submesoscale eddy structures. In the Barents Sea, eddy structures have been recorded almost within the entire sea area (Fig. 1). Single eddies and eddy structures of various forms: spiral, fungous and chain-like were detected. 2,934 in all small eddy structures were found, among which structures with a cyclonic type $(C n)-2383$ pcs (81\%) predominated. The highest frequency of occurrence of eddies was monitored in the following regions: the northwest of the Franz Josef Land, near the West Spitsbergen eastern coast, the southwestern part of the sea (in the area of the Atlantic water entrance), the central part of the strait between the Franz Josef Land and the Novaya Zemlya, in the Kanin Nos area. Here, the eddies were observed even more often than in every tenth shot. The highest occurrence (more often than in every third image, that is, 33\% of the images per considered grid unit) was noted in the area north-north-east of Rybachy Peninsula, where 14 eddies per $1,000 \mathrm{~km}^{2}$ were registered. Spatial distribution of the eddy structure dimensions showed that on average large eddies (over 7-8 km) were detected in the Atlantic water propagation area (the southwestern part of the sea). Eddies with sizes less than $2 \mathrm{~km}$ were recorded mainly to the northeast of the Spitsbergen, as well as between the Franz Josef Land and the Novaya Zemlya. Eddies with a diameter of $\sim 2-$ $4 \mathrm{~km}$ were most often observed, both among the cyclonic and anticyclonic (Ac) ones, with an average value of $3.6 \mathrm{~km}$, mode and median of 2.8 and $2 \mathrm{~km}$, respectively.

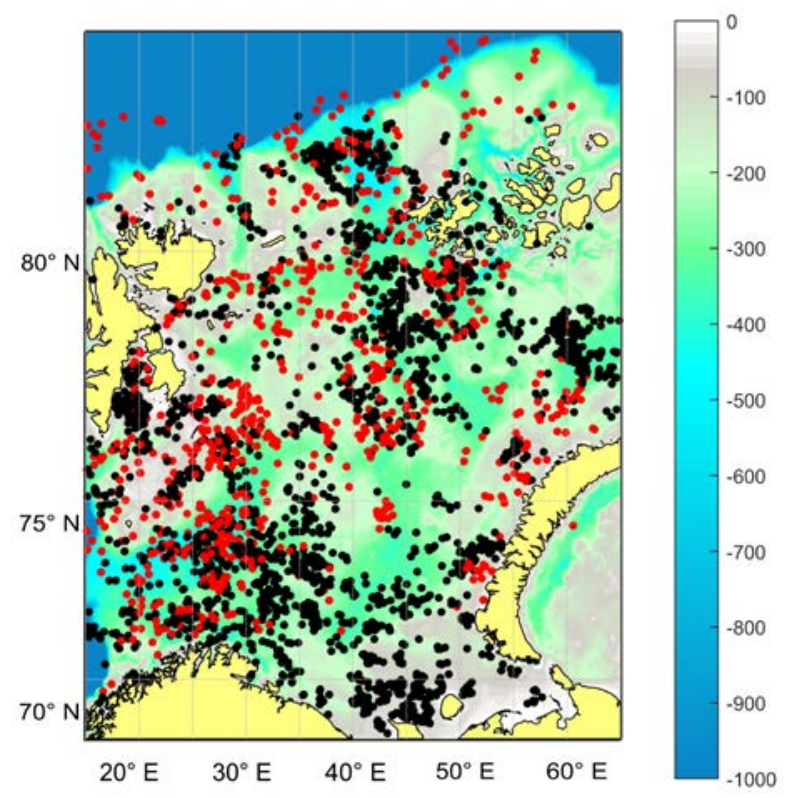

Fig. 1. Spatial distribution of the locations of the small eddy centers in 2007 (black circles) and 2011 (red circles). Depth scale is in meters

An analysis of the intra-seasonal distribution of eddy structures in the Barents Sea showed (Tab. 1) that from June to July their number increased and from July to October decreased by 4.5 times. The peak of the eddy activity was in July and equaled to 854 eddies per month. However, the maximum of anticyclonic eddies was observed in August, although it slightly differed from the July figure (by 9 eddies). 
The mean monthly diameter of the eddies varies from 2.3 to $4.2 \mathrm{~km}$. At the same time, from June to October, there is a tendency to its reduction. Almost in all the months, the mean monthly diameters of anticyclonic eddies were larger than those of cyclonic eddies, while the latter were recorded several times more frequently every month.

Table 1

Parameters of the eddies in the Barents Sea during the warm season, Ac denotes the anticyclonic eddies, $\mathrm{Cn}$ - the cyclonic ones and (Ac + Cn) all the eddies

\begin{tabular}{l|r|c|c|c|c|c}
\hline \multirow{2}{*}{ Month } & \multicolumn{3}{|c|}{ Number of eddies, pcs } & \multicolumn{3}{c}{ Mean diameter, km } \\
\cline { 2 - 7 } & \multicolumn{1}{|c}{$A c$} & $C n$ & $A c+C n$ & $A c$ & $C n$ & $A c+C n$ \\
\hline June & 116 & 563 & 679 & 4.7 & 4.2 & 4.2 \\
July & 156 & 698 & 854 & 5.9 & 3.7 & 4.1 \\
August & 167 & 549 & 716 & 3.4 & 3.3 & 3.3 \\
September & 87 & 411 & 498 & 2.4 & 2.4 & 2.4 \\
October & 25 & 162 & 187 & 2.9 & 2.2 & 2.3 \\
Sum total for & 551 & 2383 & 2934 & 4.2 & 3.4 & 3.5 \\
the season & & & & & & \\
\hline
\end{tabular}

2,187 and 747 eddy structures had been registered for 2007 and 2011, respectively (Tab. 2). As compared with 2007, there are fewer radar images for 2011, the coverage of images is more uneven: the northern part of the sea is mostly covered and the southeastern part of it is almost not covered. For this reason this part is not considered when comparing eddy areas. In 2011 the eddies are recorded northward than in 2007, due to the larger ice-free water region [15]. But on the whole, the situation of the eddy structure clusters is similar in the both years (as well as the regions with the highest occurrence, except for the southeastern part of the sea), and the general regularities within the season throughout the data array (Tab. 1) remain separately for each year (Tab. 2). About $90 \%$ of the small eddy structures were up to $6 \mathrm{~km}$ in size, which allows them to be classified as a submeasoscale ones, with diameters ranging from 2 to $4 \mathrm{~km}$ prevailing in both years, from 20 to $30 \%$ of the eddies had size of up to $2 \mathrm{~km}$, from 10 to $20 \%-4 \ldots 6 \mathrm{~km}$.

The generalization carried out shows that submesoscale eddies are a common phenomenon throughout the Barents Sea. It is interesting that some of their characteristics and patterns established by eddy manifestations on the Barents Sea surface were observed in other regions of the World Ocean. In particular, it concerns the predominance of cyclonic eddies over the amount of rotation of the eddies with anticyclonic rotation [16-19], although most of the Beaufort Sea detected smallscale eddies have anticyclonic rotation [20], which developed within the existing in summer anticyclonic circulation of the surface waters. Probably, a background cyclonic vorticity is a favorable condition for the dominance of cyclonic submesoscale eddies (in the Northern Hemisphere). 
Parameters of the eddies in the Barents Sea in 2007 and 2011, Ac denotes the anticyclonic eddies, $\mathrm{Cn}$ - the cyclonic ones and $(\mathrm{Ac}+\mathrm{Cn})$ is all the eddies

\begin{tabular}{|c|c|c|c|c|c|c|}
\hline \multirow{2}{*}{ Month } & \multicolumn{3}{|c|}{ Number of eddies, pcs } & \multicolumn{2}{|c|}{ Mean (min - max) diameter, km } & \multirow{2}{*}{$\begin{array}{l}\begin{array}{l}\text { Mean diame- } \\
\text { ter, km }\end{array} \\
A c+C n \\
\end{array}$} \\
\hline & Ac & $\mathrm{Cn}$ & $A c+C n$ & $A c$ & $\mathrm{Cn}$ & \\
\hline \multicolumn{7}{|c|}{2007} \\
\hline June & 103 & 390 & 493 & $4.7(0.3-17.1)$ & $4(0.3-15.6)$ & 4.2 \\
\hline July & 139 & 498 & 637 & $6(0.2-21)$ & $3,8(0.2-25)$ & 4.3 \\
\hline August & 156 & 366 & 522 & $3.5(1-18.3)$ & $3,7(0.7-20.4)$ & 3.6 \\
\hline September & 83 & 279 & 362 & $2.4(0.5-12.1)$ & $2,2(0.2-15.9)$ & 2.2 \\
\hline October & 25 & 148 & 173 & $2.9(0.5-10.6)$ & $2,2(0.4-9.8)$ & 2.3 \\
\hline Sum total & 506 & 1681 & 2187 & $4.2(0.2-21)$ & $3,4(0.2-25)$ & 3.6 \\
\hline \multicolumn{7}{|c|}{2011} \\
\hline June & 13 & 173 & 186 & $4,6(1.6-10.3)$ & $4.4(1.6-12.9)$ & 4.4 \\
\hline July & 17 & 200 & 217 & $5.2(1.9-14.5)$ & $3.5(0.9-15.6)$ & 3.6 \\
\hline August & 11 & 183 & 194 & $3.1(1.7-6.4)$ & $2.3(1.2-5.4)$ & 2.4 \\
\hline September & 4 & 132 & 136 & $2.0(1.5-2.6)$ & $2.7(1.0-9.9)$ & 2.7 \\
\hline October & & 14 & 14 & & $2.5(1.0-4.9)$ & 2.5 \\
\hline Sum total & 45 & 702 & 747 & $4.2(1.6-14.5)$ & $3.3(0.9-15.6)$ & 3.3 \\
\hline
\end{tabular}

Frontal zones. In the both years the Marginal Ice frontal zone was traced in the northern part of the sea to the west of the Spitsbergen and south of the Franz Josef Land, changing its position after the ice edge shift. At the same time, at the beginning and the end of the warm period in the western part of the sea, the Marginal and Polar frontal zones were located close to each other. For the period from June to October, the southernmost position of the Marginal Ice frontal zone was recorded in early June, the northernmost - in the middle of August. Its displacement for the season exceeded $450 \mathrm{~km}$. The width of the Marginal Ice frontal zone, based on the data of three meridional sections, ranged from 44 to $122 \mathrm{~km}$ in 2007 (mean about $80 \mathrm{~km}$ ) and in 2011 - from 44 to $139 \mathrm{~km}$ (mean $90 \mathrm{~km}$ ). In the both years in the frontal zone, a stepped type of thermal structure predominated. The maximum gradient of sea surface temperature in 2007 was $0.07^{\circ} \mathrm{C} / \mathrm{km}$, and in 2011 $0.05^{\circ} \mathrm{C} / \mathrm{km}$.

The Polar frontal zone was situated mainly in the central part of the sea and was oriented from west to east. Its width, according to the aforementioned sections, in 2007 varied from 44 to $206 \mathrm{~km}$ (the mean is value $130 \mathrm{~km}$ ), and in 2011 - from 53 to $167 \mathrm{~km}$ (on average $120 \mathrm{~km}$ ). The position of the Polar frontal zone in the western part of the sea was quasi-permanent, the maximum gradients of $0.05^{\circ} \mathrm{C} / \mathrm{km}$ were also observed here. The greatest dynamics of the frontal zone and its front was recorded in the eastern part of the sea, where the gradients were much weaker than in the western part. Both in the Marginal and Polar frontal zones, in both years the stepped type of thermal structure was most often recorded.

Both fronts showed a significant temporal dynamics, which was reflected both in the decadal averaging interval and in the monthly one. It should be noted that the intensive dynamics of the fronts took place within the monthly intervals. Moreover, 
comparing the monthly averages and the average decadal positions of the frontal lines (Fig. 2), it follows that in studying the intra-season frontal dynamics it is desirable to focus on to the decadal data, characterizing the significant mesoscale variability of the front position.

Analysis of composite maps showed that a quarter of all eddies were recorded inside and on the periphery of the frontal variability zone of for the entire period, while only $1 \%$ less eddy structures were detected in the Polar Front zone than in the Marginal one. In the areas of decadal variability of the fronts, eddies of small size (up to $4 \mathrm{~km}$ ) with cyclonic rotation type prevailed. However, occasionally on the periphery of the frontal zones, large formations (over $8 \mathrm{~km}$ in diameter) with an anticyclonic rotation type were observed.

Maximum number of eddies in the variability area of the Marginal and Polar Fronts was registered in July 2007 (20 and 24\% respectively of the total for the month). In the same month there was an eddy activity peak and the displacement of the decadal fronts was the highest (Fig. 2b). The aforementioned fact of the frequent manifestations of small eddies in the frontal zones, and in our case - in the variability zone of surface fronts, suggests the relationship of these eddies with the frontal activity. In June and August from 10 to 13\% eddies per month inside and on the periphery of each of the zones was recorded, while in September, there were only $14 \%$ of the number of eddies in September in these two areas.

However, the formation of submesoscale eddies with a short lifetime cannot always be identified with any mechanism based on available satellite information, especially since these mechanisms can work in combination. Nevertheless, this comparison allows stating the submesoscale eddies to be more often manifested in the first half of summer, when the fronts are more dynamic and the seasonal heating of the upper layer has not reached its maximum yet.
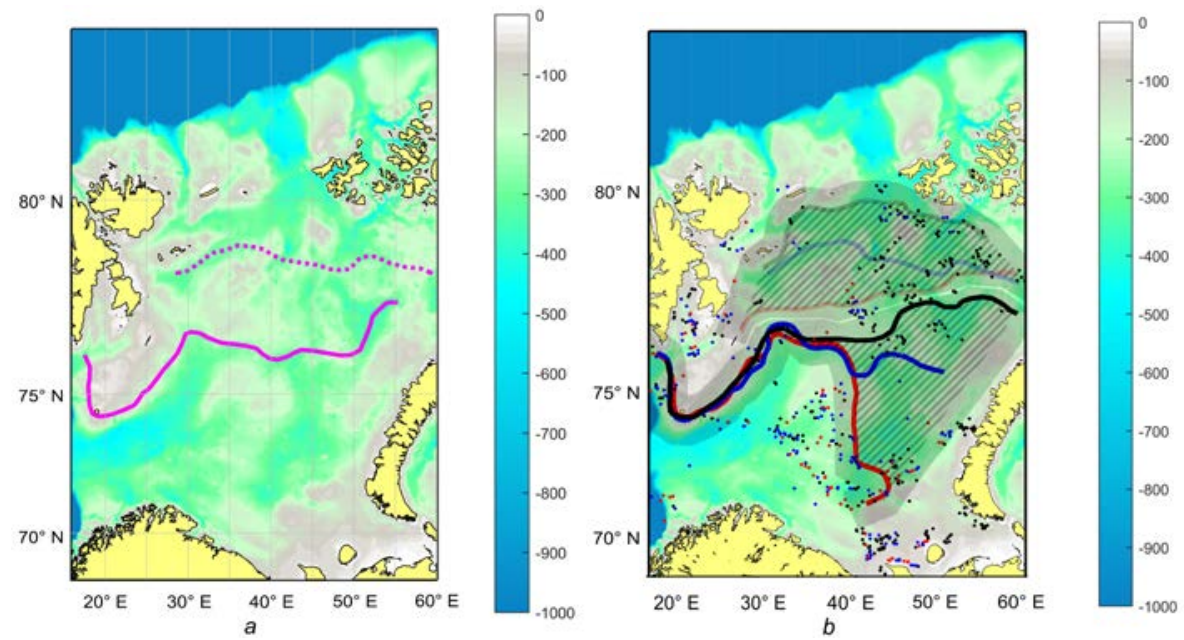

Fig. 2. Monthly average ( $a$ ) and decadal (b) locations of the Marginal ice front (dashed line) and the Polar front (solid line) in July, 2007. Pink color denotes their monthly average positions, red - in the $1^{\text {st }}$ decade, blue - in the $2^{\text {nd }}$ decade and black - in the $3^{\text {rd }}$ one. Slanting lines show the areas of variability of the fronts' decadal locations in July, 2007 and grey color - the $50 \mathrm{~km}$ zone close to the area of variability. Depth scale is in meters 
Conclusion. Within the scope of the works on radar images for June - October 2007 and 2011 the following characteristics of small eddies were detected: the position of the center, the type of rotation and the diameter. The analysis of these characteristics made it possible to identify the intraseasonal and interannual features of the spatiotemporal variability of the parameters of small eddies, and their comparison with frontal dynamics made it possible to evaluate their relationship.

In total, about 3,000 small eddy structures were recorded in the Barents Sea, which were most often observed to the northwest off the Franz Josef Land, near the eastern coast of the Western Spitsbergen, between the Franz Josef Land and the Novaya Zemlya, in the southwestern part of the sea (in the area of entrance of the Atlantic waters) and near the Kanin Nos peninsula. But their absolute maximum is recorded to the northeast off the Rybachy Peninsula. In both years the eddy activity peak falls on July, when more than a quarter of the eddy structures was recorded on the whole, with eddies with the diameters $2-4 \mathrm{~km}$ and with a cyclonic rotation type prevailing. The mean parameters of the eddies from year to year and during the warm season totally persisted.

In both years, in the Barents Sea area, the position of the Marginal and Polar fronts was identified according to the processing results of the decadal and monthly averages of sea-surface temperature and its gradients. In addition, the mean widths for each frontal zone of the fronts identified were estimated. With a mean width of both frontal zones of about $100 \mathrm{~km}$, the maximum width of the Marginal Ice frontal zone reached almost $140 \mathrm{~km}$, and the one of the Polar - nearly $200 \mathrm{~km}$. It was also revealed that the Marginal front during the warm period can shift over a distance of $450 \mathrm{~km}$ from June to the end of August - the beginning of September, and the Polar front is quasi-stationary in the western part of the sea and is dynamic in its eastern part. Thus, the decadal data was the best to reflect the synoptic variability.

Comparison of the eddy locations with variability of the fronts positions for each month (based on the data of 2007) shows that the submesoscale structures are often recorded within these regions (a quarter of the eddies of the season), at that the period of the highest eddy activity in July coincides with that of the strongest synoptic and mesoscale dynamics of the fronts.

\section{REFERENCES}

1. Terziev, F.S. ed., 1990. Gidrometeorologiya i Gidrokhimiya Morey SSSR. Tom 1. Barentsevo More. Vyp. 1. Gidrometeorologicheskie Usloviya [Hydrometeorology and Hydrochemistry of the Seas of the USSR. Vol. 1. The Barents Sea. Part 1: Hydrometeorological Conditions]. Leningrad: Gidrometeoizdat, 280 p. (in Russian).

2. Ozhigin, V.K., Ivshin, V.A., Trofimov, A.G., Karsakov, A.L. and Anciferov, M.Y., 2016. Vody Barentseva Morya: Struktura, Tsirkulyatsiya, Izmenchivost' [The Barents Sea Water: Structure, Circulation, and Variability]. Murmansk: PINRO, 259 p. (in Russian).

3. Oziel, L., Sirven, J. and Gascard, J.-C., 2016. The Barents Sea Frontal Zones and Water Masses Variability (1980-2011). Ocean Science, [e-journal] 12(1), pp. 169-184. doi:10.5194/os-12-169-2016

4. Fer, I. and Drinkwater, K., 2014. Mixing in the Barents Sea Polar Front near Hopen in Spring. Journal of Marine Systems, [e-journal] 130, pp. 206-218. doi:10.1016/j.jmarsys.2012.01.005

5. Bystrov, V.P., Volodin, V.V., Taradin, S.P. and Shcherbachenko, S.V., 1998. Opyt Avtomatizirovannogo Kartografirovaniya Gidrologicheskikh Frontov (na Primere Barentseva morya) [The Experience of Automated Mapping of Hydrological Fronts (on the Example of the Barents Sea)]. Working paper. Moscow: IKI. (in Russian, unpublished). 
6. Lebedev, I.A., 1992. O Vliyanii Glubinnykh Atlanticheskikh Vod na Ledovo-Gidrologicheskie Protsessy v Severnoi Chasti Barentseva Morya [On Influence of Deep Atlantic Waters on the Ice-Hydrological Processes in the Northern Part of the Barents Sea]. In: G.V. Alekseev and A.P. Makshtas eds., 1992. Proceedings of the Arctic and Antarctic Research Institute, vol. 430. Saint Peterburg: Gidrometeoizdat, pp. 145-156 (in Russian).

7. Rodionov, V.B. and Kostyanoy, A.G, 1998. Okeanicheskie Fronty Morei Severo-Evropeiskogo Basseina [Oceanic Fronts of the North-European Basin Seas]. Moscow: GEOS, 290 p. (in Russian).

8. Carroll, M.L., Ambrose, W.G.J., Locke, W.L., Ryan, S.K. and Johnson, B.J., 2014. Bivalve Growth Rate and Isotopic Variability across the Barents Sea Polar Front. Journal of Marine Systems, [e-journal] 130, pp. 167-180. doi:10.1016/j.marpolbul.2009.02.022

9. Morozov, A.N., Pavlov, V.K., Pavlova, O.A. and Fedorov, S.V., 2017. Polar Frontal Zone of the Barents Sea Western Trough Based on Direct Measurements in 2007. Physical Oceanography, [e-journal] (2), pp.36-50. doi:10.22449/1573-160X-2017-2-36-50

10. Johannessen, O.M. and Foster, L.A., 1978. A Note on the Topographically Controlled Oceanic Polar Front in the Barents Sea. Journal of Geophysical Research, [e-journal] 83(C9), pp. 4567-4571. doi:10.1029/JC083iC09p04567

11. Kushnir, V., Pavlov, V., Morozov, A. and Pavlova, O., 2011. "Flashes” of Chlorophylla Concentration Derived from in Situ and Remote Sensing Data at the Polar Front in the Barents Sea. The Open Oceanography Journal, [e-journal] 5, pp. 14-21. doi:10.2174/1874252101105010014

12. Lebedev, I.A, 1992. Nekotorye Rezul'taty Statisticheskogo Analiza Sinopticheskoi i Mezomasshtabnoi Izmenchivosti Temperatury Vody v Barentsevom More [Some Results of Statistical Analysis of Synoptic and Mesoscale Variability of Water Temperature in the Barents Sea]. In: G.V. Alekseev and A.P. Makshtas eds., 1992. Proceedings of the Arctic and Antarctic Research Institute, vol. 430. Saint Peterburg: Gidrometeoizdat, pp. 169-181 (in Russian).

13. Kostyanoy, A.G., Lebedev, I.A., Novikov, B.A. and Rodionov, V.B, 1992. O Vikhreobrazovanii v Polyarnoi Frontal'noi Zone Barentseva Morya [On eddy formation in the Polar Frontal Zone of the Barents Sea]. In: S.L. Dzhenyuk and G.G. Zykova eds., 1992. Proceedings of the Arctic and Antarctic Research Institute, vol. 426. Saint Peterburg: Gidrometeoizdat, pp. 19-32 (in Russian).

14. Atadzhanova, O.A., Zimin, A.V., Romanenkov, D.A. and Kozlov, I.E., 2017. Satellite Radar Observations of Small Eddies in the White, Barents and Kara Seas. Physical Oceanography, [e-journal] (2), pp. 75-83. doi:10.22449/1573-160X-2017-2-75-83

15. Mikhailova, N.V. and Yurovsky, A.V., 2017. Analysis of Principal Components of the Sea Ice Concentration Fields in the Barents Sea. Physical Oceanography, [e-journal] (2), pp. 1118. doi:10.22449/1573-160X-2017-2-11-18

16. Mityagina, M.I. and Lavrova, O.Yu., 2009. Sputnikovye Nablyudeniya Vikhrevykh i Volnovykh Protsessov v Pribrezhnoi Zone Severo-Vostochnoi Chasti Chernogo Morya [Satellite Observations of Eddy and Wave Processes in the Coastal Waters of the North-Eastern Black Sea]. Issledovanie Zemli iz Kosmosa, (5). pp. $72-79$ (in Russian).

17. Zimin, A.V., Atazhanova, O.A., Romanenkov, D.A., Kozlov, I.E. and Chapron, B., 2016. Submezomasshtabnye Vikhri v Belom More po Dannym Sputnikovykh Radiolokatsionnykh Izmerenii [Submesoscale Eddies in the White Sea Based on Satellite SAR Data]. Issledovanie Zemli iz Kosmosa, (1-2), pp. 129-135. doi:10.7868/S020596141506010X (in Russian).

18. Karimova, S.S., 2012. Spiral Eddies in the Baltic, Black and Caspian Seas as Seen by Satellite Radar Data. Advances in Space Research, [e-journal] 50(8), pp. 1107-1124. doi:10.1016/j.asr.2011.10.027

19. Timmermans, M.-L. and Winsor, P., 2013. Scales of Horizontal Density Structure in the Chukchi Sea Surface Layer. Continental Shelf Research, [e-journal] 52, pp. 39-45. doi:10.1016/j.csr.2012.10.015

20. D'Asaro, E.A., 1988. Generation of Submesoscale Vortices: A New Mechanism. Journal of Geophysical Research, [e-journal] 93(C6), pp.6685-6693. doi:10.1029/JC093iC06p06685 
About the authors:

Oksana A. Atadzhanova - Junior Research Associate, Shirshov Institute of Oceanology, Russian Academy of Science (36, Nahimovskiy pr., Moscow, 117997, Russia); Russian State Hydrometeorological University (98, Malookhtinsky prospect, Saint Petersburg, 195196, Russia), Scopus Author ID: 57188718743, oksana.atadzhanova@gmail.com

Aleksey V. Zimin - Leading Research Associate, Shirshov Institute of Oceanology, Russian Academy of Science (36, Nahimovskiy pr., Moscow, 117997, Russia), Dr.Sci. (Geogr.), assistant professor, Scopus Author ID: 55032301400, ResearcherID: C-5885-2014, ORCID ID: 0000-00031662-6385, zimin2@mail.ru

Egor I. Svergun - Engineer, Shirshov Institute of Oceanology, Russian Academy of Science (36, Nahimovskiy pr., Moscow, 117997, Russia); Russian State Hydrometeorological University (98, Malookhtinsky prospect, Saint Petersburg, 195196, Russia), e-mail: svergun@ocean.rshu.ru

Aleksandr A. Konik - Engineer, Shirshov Institute of Oceanology, Russian Academy of Sciences (36, Nahimovskiy pr., Moscow, 117997, Russia); Russian State Hydrometeorological University (98, Malookhtinsky prospect, Saint Petersburg, 195196, Russia), e-mail: konikrshu@gmail.com

Contribution of the co-authors:

Oksana A. Atadzhanova - data analysis, writing a draft, reference review preparation

Aleksey V. Zimin - scientific supervision and checking of the results

Egor I. Svergun - radar data processing, building of the composite maps

Aleksandr A. Konik - sea surface temperature processing

All the authors have read and approved the final manuscript.

The authors declare that they have no conflict of interest. 